\title{
PENGARUH KONSENTRASI SUKROSA PADA INDUKSI EMBRIO SOMATIK \\ DUA KULTIVAR KACANG TANAH (Arachis hypogaea L.) SECARA IN VITRO
}

Titik Inayah*

\begin{abstract}
ABSTRAK
Tujuan dari penelitian ini adalah untuk mengetahui pengaruh berbagai konsentrasi sukrosa terhadap induksi embrio somatik kacang tanah pada setiap kultivar kacang tanah yang diuji dan mencari konsentrasi sukrosa yang paling baik untuk menginduksi embrio somatik pada setiap kultivar kacang tanah yang dicoba. Percobaan dilakukan pada dua kultivar kacang tanah, yaitu kacang tanah Jerapah dan kacang tanah Sima, percobaan ini dilaksanakan dalam rancangan acak lengkap (RAL) dengan 10 ulangan. Setiap satuan percobaan terdiri dari 1 botol yang berisi 5 eksplan leaflet kacang tanah. Perlakuan yang diterapkan pada setiap kultivar dengan menggunakan berbagai konsentrasi sukrosa yaitu 0, 10, 20, 30, dan $40 \mathrm{~g} / \mathrm{l}$. Untuk variabel jumlah embrio, homogenitas ragam diuji dengan uji Bartlett. Data yang diperoleh dianalisis dengan sidik ragam. Perbedaan nilai tengah perlakuan diuji dengan uji Beda Nyata Terkecil (BNT) pada taraf nyata 5\%. Dari hasil penelitian dan pengamatan yang telah dilakukan, maka dapat disimpulkan sebagai berikut yaitu, 1) Pada kultivar Jerapah, konsentrasi sukrosa berpengaruh terhadap rata-rata jumlah embrio somatik per eksplan dan persentase kalus embriogenik. Konsentrasi sukrosa dalam media yang baik dalam menghasilkan rata-rata embrio somatik per eksplan adalah $20 \mathrm{~g} /$. konsentrasi sukrosa dalam media yang optimum dalam menghasilkan pesentase kalus embriogenik adalah 10 dan $20 \mathrm{~g} / \mathrm{l}$. 2)Pada kultivar Sima, konsentrasi sukrosa dalam media yang baik dalam menghasilkan rata-rata embrio somatik per eksplan adalah $30 \mathrm{~g} /$. konsentrasi sukrosa dalam media yang optimum dalam menghasilkan persentase kalus embriogenik adalah $40 \mathrm{~g} / \mathrm{l}$.
\end{abstract}

Kata kunci: embrio somatic, konsentrasi sukrosa, in vitro 


\begin{abstract}
The purpose of this study was to determine the effect of various concentrations of sucrose on somatic embryo induction of peanuts on every peanut cultivars tested and find the best sucrose concentrations to induce somatic embryos on any peanut cultivars were tested. The experiments were performed on two peanut cultivars, namely peanuts and peanut Giraffe Sima, an experiment was conducted in a completely randomized design (CRD) with 10 replications. Each experimental unit consisted of one bottle containing 5 explants leaflet peanuts. The treatments were applied to each cultivars using different concentrations of sucrose were 0,10, 20,30, and $40 \mathrm{~g} / \mathrm{l}$. For variable number of embryos, homogeneity of variance was tested with Bartlett's test. Data were analyzed by analysis of variance. Differences in median value treatments tested with Least Significant Difference (LSD) at the $5 \%$ significance level. From the results of observation and research that has been done, it can be concluded as follows, namely, 1) On Giraffes cultivars, sucrose concentrations affect the average number of somatic embryos per explant and the percentage of embryogenic callus. The concentration of sucrose in the media in both the average yield of somatic embryos per explant was $20 \mathrm{~g} / \mathrm{l}$. the concentration of sucrose in the media in generating optimum pesentase embryogenic callus was 10 and $20 \mathrm{~g} / \mathrm{l}$. 2) On cultivars Sima, the concentration of sucrose in the media in both the average yield of somatic embryos per explant was $30 \mathrm{~g} / \mathrm{l}$. the concentration of sucrose in an optimum medium to generate embryogenic callus percentage was $40 \mathrm{~g} / \mathrm{l}$.
\end{abstract}

Keywords: somatic embryos, sucrose concentration, in vitro

\section{PENDAHULUAN}

Kacang tanah (Arachis hipogaea L.) merupakan salah satu tanaman palawija yang berguna untuk bahan pangan, pakan, dan bahan baku industri. Selain itu, kacang tanah merupakan sumber protein nabati yang cukup penting dan di Indonesia kacang tanah menempati urutan kedua setelah kedelai. Kacang tanah sebagian besar ditanam oleh petani di tegalan, lahan tadah hujan $(70 \%)$, dan sisanya $(30 \%)$ ditanam setelah padi di sawah yang berpengairan (Heriyanto dan Subagio, 1998). Penggunaan kacang tanah yang semakin beragam mengakibatkan permintaan kacang tanah semakin meningkat dari tahun ke tahun sejalan dengan pertambahan penduduk, kebutuhan gizi masyarakat, diversifikasi pangan dan peningkatan kapasitas produksi (Srilestari, 2005).

Dalam upaya meningkatkan produksi kacang tanah dapat dilakukan dengan teknik budidaya yang baik dan tidak merusak lingkungan. Kendala serangan hama dan penyakit perlu diatasi dengan mengembangkan varietas yang resisten melalui program perakitan tanaman 
transgenik dan penyediaan bibit bermutu. Salah satu cara yang paling tepat adalah dengan teknik kultur jaringan, yaitu teknik menumbuh-kembangkan bagian tanaman, baik berupa sel, jaringan, atau organ dalam kondisi aseptik secara in vitro (Yusnita, 2003). Perbanyakan tanaman secara in vitro untuk jangka panjang diharapkan dapaat membantu program pemuliaan melalui rekayasa genetika.

Perbanyakan tanaman melalui kultur jaringan dapat dilakukan dengan dua cara yaitu organogenesis dan embriogenesis somatik. Organogenesis adalah proses pembentukan organ seperti tunas atau akar, baik secara langsung dari eksplan atau secara tidak langsung melalui pembentukan kalus terlebih dulu. Sedangkan embriogenesis somatik adalah proses pembentukan embrio yang bukan berasal dari zigot, tetapi dari sel somatik tanaman (Gunawan, 1988). Embrio somatik biasanya berasal dari sel tunggal yang kompeten dan berkembang membentuk fase globular, hati, torpedo, dan akhirnya menjadi embrio somatik dewasa yang siap dikecambahkan untuk membentuk planlet/tanaman utuh (Finer dan Mc Mullen, 1991 dalam Finer et al., 1996)

Dalam kultur jaringan, untuk mendukung pertumbuhan yang optimal diperlukan bahan-bahan organik yang ditambahkan ke dalam media. Beberapa faktor penting yang mempengaruhi pembentukan embrio somatik adalah jenis eksplan, sumber nitrogen dan gula serta zat pengatur tumbuh. Menurut yusnita (2003), salah satu komponen penting yang harus ada dalam media kultur adalah gula. Gula yang paling sering digunakan adalah sukrosa. Sukrosa dalam media kultur berfungsi sebagai sumber energy, karena umumnya bagian tanaman atau eksplan yang dikulturkan tidak autotrof dan mempunyai laju fotosintesis sangat rendah. Tujuan dari penelitian ini adalah ; 1) Mengetahui pengaruh konsentrasi sukrosa terhadap induksi embrio somatik kacang tanah pada setiap kultivar yang dicoba (Jerapah dan Sima), 2) Mencari konsentrasi sukrosa yang paling baik untuk menginduksi embrio somatik pada setiap kultivar yang dicoba (Jerapah dan Sima).

\section{METODE PENELITIAN}

Percobaan pada kedua kultivar kacang tanah Jerapah dan Sima dilaksanakan dalam rancangan acak lengkap (RAL) dengan 10 ulangan. Setiap satuan percobaan terdiri dari 1 botol yang berisi 5 eksplan leaflet kacang tanah. Perlakuan yang diterapkan pada setiap kultivar adalah berbagai konsentrasi sukrosa yaitu 0, 10, 20, 30, dan $40 \mathrm{~g} / 1$. Untuk variabel jumlah embrio, homogenitas ragam diuji dengan uji Bartlett. Data yang diperoleh dianalisis dengan sidik ragam. Perbedaan nilai tengah perlakuan diuji dengan uji Beda Nyata Terkecil (BNT) pada taraf nyata 5\%.

\section{Pelaksanaan Penelitian}

Sterilisasi Alat

Peralatan yang digunakan meliputi botol-botol kultur, alat-alat diseksi, dan alat-alat gelas yang dicuci terlebih dahulu. Alat-alat tersebut kemudian disterilisasi 
dengan menggunakan autoclave selama 30 menit pada temperature 121 oC dengan tekanan $1.2 \mathrm{kgf} / \mathrm{cm} 2$.

\section{Media Perlakuan}

Media tanam yang digunakan adalah media MS (Murashige dan Skoog, 1962) dengan penambahan picloram $16 \mu \mathrm{M}$. Pada media perlakuan ditambahkan dengan berbagai konsentrasi sukrosa masingmasing dengan konsentrasi 0, 10, 20, 30, dan $40 \mathrm{~g} / \mathrm{l}$. Untuk pemadat media ditambahkan agar swallow globe sebanyak $6 \mathrm{~g} / \mathrm{l}$ kemudian $\mathrm{pH}$ diatur menjadi 5,8. Kemudian media dimasak hingga mendidih, setelah itu tuangkan kurang lebih $30 \mathrm{ml}$ ke botol-botol kultur yang sebelumnya sudah disterilisasi menggunakan autoclave. Botol-botol yang sudah terisi media ditutup dengan alumunium foil dilapisi dengan plastik dan diikat karet gelang. Botol kultur kemudian disterilkan menggunakan autoclave pada suhu 121 oC selama 15-20 menit pada tekanan $1,2 \mathrm{kgf} / \mathrm{cm} 2$.

\section{Eksplan}

Eksplan yang ditanam adalah bagian leaflet dari kacang tanah yang diambil dengan menggunakan pisau scalpel dengan hati-hati karena leaflet kacang tanah mudah sekali rusak. Sebelum leaflet diambil dari benih kacang tanah, benih disterilisasi terlebih dahulu dalam larutan yang terdiri dari campuran aquades $150 \mathrm{ml}$, ditambahkan dengan $50 \mathrm{ml}$ natrium hipoklorit/bayclin (30\%) dan 10 tetes tween 20, dikocok selama 15 menit hingga benih berubah warnanya menjadi putih. Kemudian benih kacang tanah dibilas sebanyak 3 kali dengan air steril. Berikut adalah gambar leaflet kacang tanah yang akan ditanam pada media kultur.

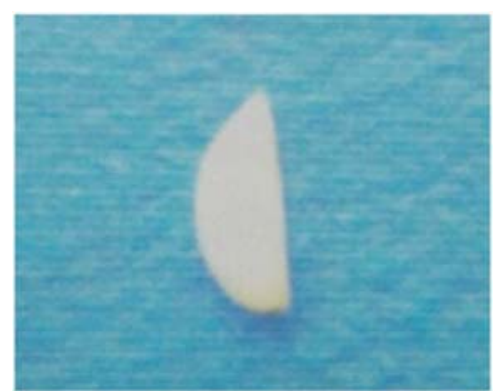

Gambar 9. Eksplan leaflet kacang tanah

\section{Penanaman Eksplan}

Penanaman eksplan dilakukan secara aseptik dalam laminar air flow cabinet secara aseptik menggunakan alat pisau scalpel dan pinset yang sebelumnya disterilisasi dengan cara mencelupkan pisau scalpel dan pinset ke dalam botol yang berisi spirtus dan membakarnya. Tahaptahap pengambilan eksplan yaitu ; 1) Mengeluarkan benih kacang tanah dari polongnya dan memilih benih yang sehat, yaitu benih yang utuh, mulus, besarnya normal, tidak busuk, dan kulit airnya tidak kusam; 2) Membelah benih menjadi dua bagian dan mengambil benih yang mempunyai embrio beserta leafletnya; 3) Memisahkan leaflet dari embrio dan porosnya dengan hati-hati karena leaflet kacang tanah mudah rusak. Satu benih kacang tanah jumlah eksplan yang dpat diambil berkisar 5-8 leaflet; 4) Leaflet siap ditanam ke dalam botol yang berisi media agar, tiap botol ditanam sebanyak 5 leaflet. Subkultur dilakukan setiap satu bulan sekali dengan media yang baru dengan 
konsentrasi sukrosa sesuai dengan perlakuan.

\section{Ruang Kultur}

Eksplan yang sudah di tanam dalam botol diletakkan dalam ruang kultur yang bersuhu \pm 24 oC dengan tidak ada pencahayaan atau dalam kondisi gelap.

\section{Variabel Pengamatan}

Pengamatan rata-rata jumlah embrio somatik dan persentase kalus embriogenik dilakukan pada minggu ke-12. Variabel yang diamati adalah; 1) Persentase eksplan yang membentuk kalus embriogenik dilakukan dengan menghitung jumlah kalus embriogenik dibagi dengan total kalus yang terbentuk, 2) rata-rata jumlah embrio somatik yang terbentuk per eksplan.

\section{HASIL DAN PEMBAHASAN}

\section{Perkembangan Umum Kultur Pada Kultivar Jerapah dan Sima}

Berbagai tipe kalus yang dihasilkan pada eksplan leaflet dari kedua kultivar yang ditanam dalam media dengan konsentrasi sukrosa 10, 20, 30, dan $40 \mathrm{~g} / 1$.

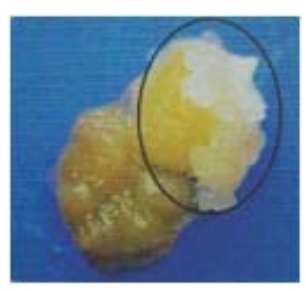

(A)

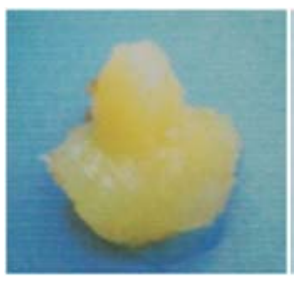

(B)

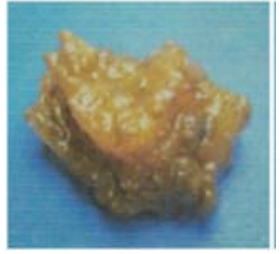

(C)

Gambar 2. Perkembangan umum bentuk kalus pada kultur berumur 12 mst. (A) eksplan yang membesar dan terjadi pembentukan kalus embriogenik (membentuk tahap-tahap embrio somatick pada daerah di dalam lingkaran). (B) membesar membentuk kalus nonembriogenik.

(C) membesar kecoklatan dan mati.

Kultivar Jerapah dan Sima yang ditanam tanpa penambahan sukrosa (0 g/l) tidak berkembang membentuk kalus sehingga tidak terbentuk embrio somatik. Hal ini disebabkan eksplan yang ditanam tumbuh secara heterotrof sehigga tanpa penambahan sukrosa tidak akan cukup mensintesis kebutuhan karbonnya (Hendaryono dan Wijayani, 2002). Dengan demikian, sukrosa harus ditambahkanke dalam media. Penambahan sukrosa akan menyediakan energi bagi pertumbuhan eksplan dan juga sebagai bahan pembangun untuk memproduksi molekul yang lebih besar yang diperlukan untuk pertumbuhan.

Umumnya sukrosa pada konsentrasi $1-5 \%$ digunakan sebagai sumber karbon. Disamping itu, ketika sukrosa diautoklaf akan terjadi hidrolisis untuk menghasilkan glukosa dan frouktosa yang dapat digunakan lebih efisien oleh eksplan dalam kultur. Sumber sukrosa dalam media juga dapat mempengaruhi proliferasi dan morfogenesis dalam kultur kalus (Eapen dan George, 1993). Sebagai sumber karbon, keberadaan sukrosa dimedia akan 
berfungsi menimbulkan tekanan osmotik media. Menurut George dan Sherrington (1984), 4/5 bagian dari potensial potensial osmotik dalam media white disebabkan oleh gula, sedangkan dalam media MS hanya setengah dari potensial osmotiknya disebabkan oleh gula.

Pada kedua kultivar, eksplan leaflet yang ditanam pada konsentrasi sukrosa 10 , 20, 30, dan $40 \mathrm{~g} / 1$ secara umum embrio somatik mulai terbentuk pada umur $4-6$ mst. Perbedaan bentuk embrio somatik antara kultivar Jerapah dan Sima yang ditanam pada konsentrasi sukrosa 10, 20, 30, dan $40 \mathrm{~g} / 1$ disebabkan karena kedua kultivar tersebut mempunyai daya regenerasi embrio somatik yang berbeda antar kultivar. Seperti yang dapat dilihat pada gambar 2 dibawah ini.

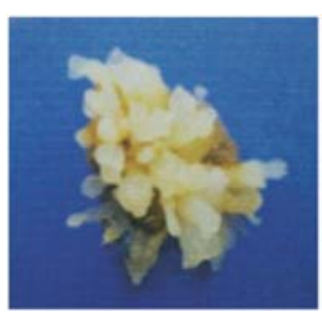

(A)

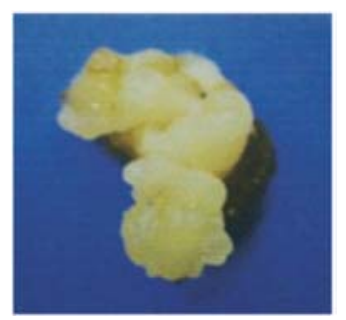

(B)
Gambar 3. (A) Kultivar Sima membentuk embrio somatik yang terlihat lebih kecil, bergerombol, dan banyak. (B) Jultivar Jerapah membentuk embrio relative yang lebih besar dengan jumlah lebih sedikit

Zuyasna et al., (2005) mengindikasikan bahwa sifat daya regenerasi embrio somatik dari eksplan daun embrio/leaflet tidak dipengaruhi oleh efek maternal dan sekaligus menunjukkan bahwa gen yang mengendalikan pembentukan embrio somatik merupakan gen inti. Hal ini memperkuat dugaan bahwa kemampuan pembentukan embrio somatik dari eksplan daun embrio (leaflet) kacang tanah dikendalikan oleh faktor genetik.

Rata-rata Jumlah Embrio Somatik dan Persentase Kalus Embriogenik Kultivar Jerapah dan Sima

Hasil pengamatan kultivar Jerapah yang dilakukan pada minggu ke 12 setelah tanam menunjukkan bahwa penambahan sukrosa yang lebih tinggi tidak meningkatkan rata-rata jumlah embrio somatik per eksplan dan persentase kalus embriogenik. Hal ini sejalan dengan penelitian Barg dan Umiel (1977) dalam George dan Sherington (1984), konsentrasi sukrosa lebih tinggi menurunan pertumbuhan dan morphogenesis kalus tembakau. Sedangkan untuk konsentrasi sukrosa terbaik dalam menghasilkan ratarata jumlah embrio somatik 20 dan $30 \mathrm{~g} / 1$. Hal ini sejalan dengan beberapa penelitian induksi embrio somatik kacang tanah yang umumnya menggunakan konsentrasi sukrosa $30 \mathrm{~g} / \mathrm{l}$, Livingstone dan Birch (1996), Sulichantini (1998), Edy et al., (2008). Rata-rata jumlah embrio somatik dan persentase kalus embriogenik dapat dilihat pada ga mbar 4 dan 5 .

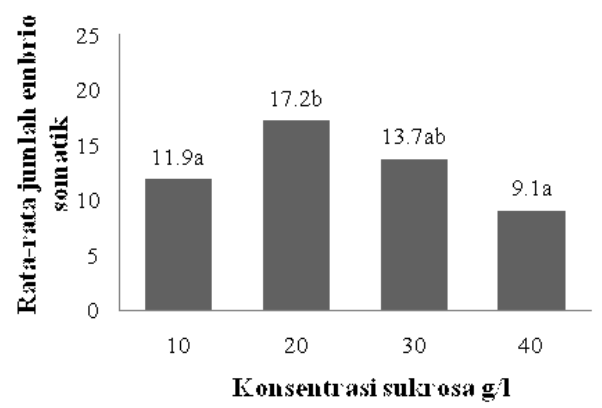


Gambar 4. Rata-rata embrio somatik per eksplan pada berbagai macam konsentrasi sukrosa $(10,20,30$, dan $40 \mathrm{~g} / 1)$ untuk kultivar jerapah. Perlakuan yang diikuti oleh huruf yang sama berarti tidak berbeda nyata pengaruhnya menurut BNT 5\% $(5,06)$

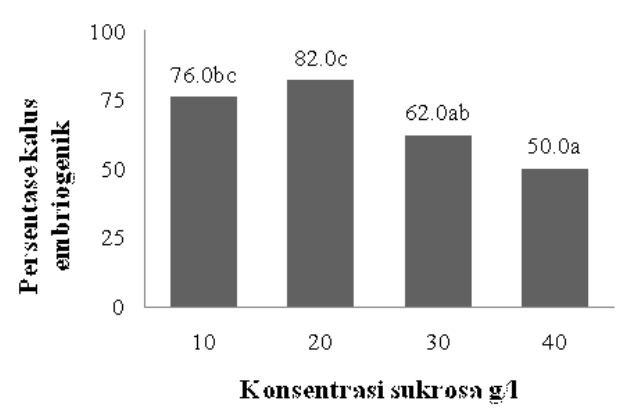

Gambar 5. Persentase kalus embriogenik pada berbagai macam konsentrasi sukrosa $(10,20$, 30, dan $40 \mathrm{~g} / \mathrm{l}$ ) untuk kultivar Jerapah.
Perlakuan yang diikuti oleh huruf yang sama berarti tidak berbeda nyata pengaruhnya menurut BNT 5\% $(19,13)$

Hasil pengamatan kultivar Sima yang dilakukan pada minggu ke 12 setelah tanam menunjukkan bahwa penambahan sukrosa yang lebih tinggi akan meningkatkan ratarata jumlah embrio somatik dan persentase kalus embriogenik. Sesuai dengan yang dikemukakan oleh George dan Sherrington (1984) bahwa penambahan sukrosa pada medium dapat meningkatkan pertumbuhan dan perkembangan planlet. Namun pada batas tertentu dimana sel telah dalam keadaan jenuh maka penambahan sukrosa justru dapat menurunkan partumbuhan dan perkembangan jaringan. Rata-rata jumlah embrio somatik dan persentase kalus embriogenik kultivar Sima dapat dilihat pada gambar 6 dan 7 .

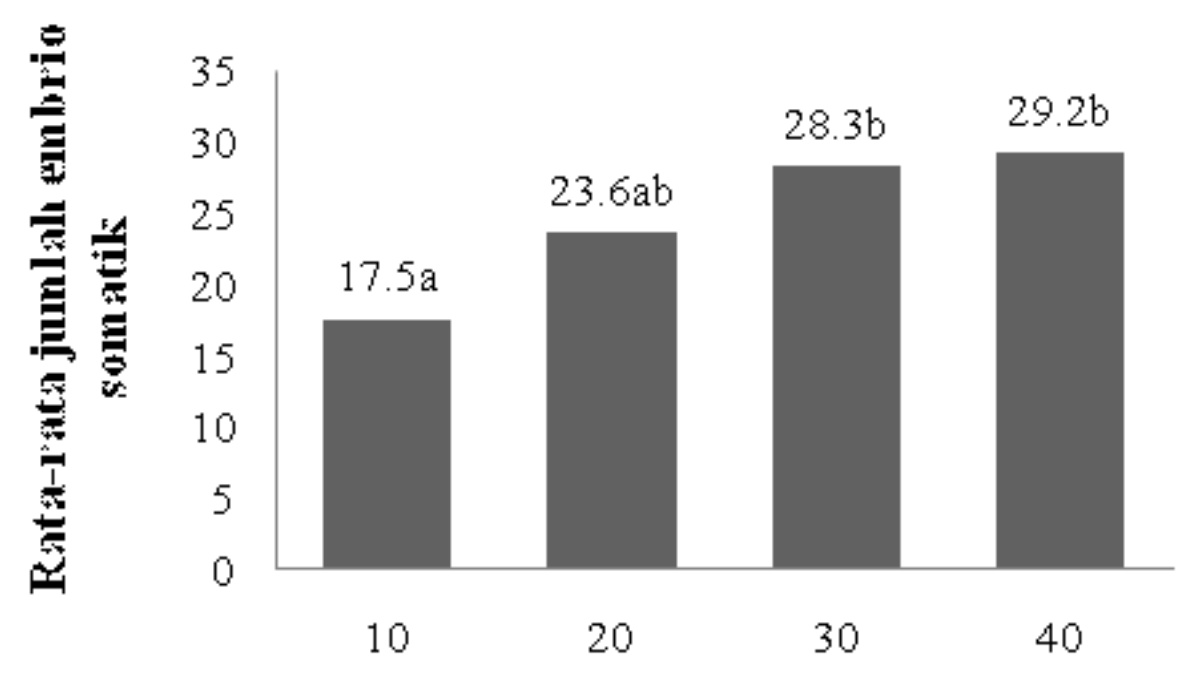

Konsentrasi sukrosn g1

Gambar 6. Rata-rata jumlah embrio somatik per eksplan pada berbagai macam konsentrasi sukrosa $(10,20,30$, dan $40 \mathrm{~g} / \mathrm{l})$ untuk kultivar Sima. Perlakuan yang diikuti oleh huruf yang sama berarti tidak berbeda nyata pengaruhnya menurut BNT 5\% $(0,99)$. 


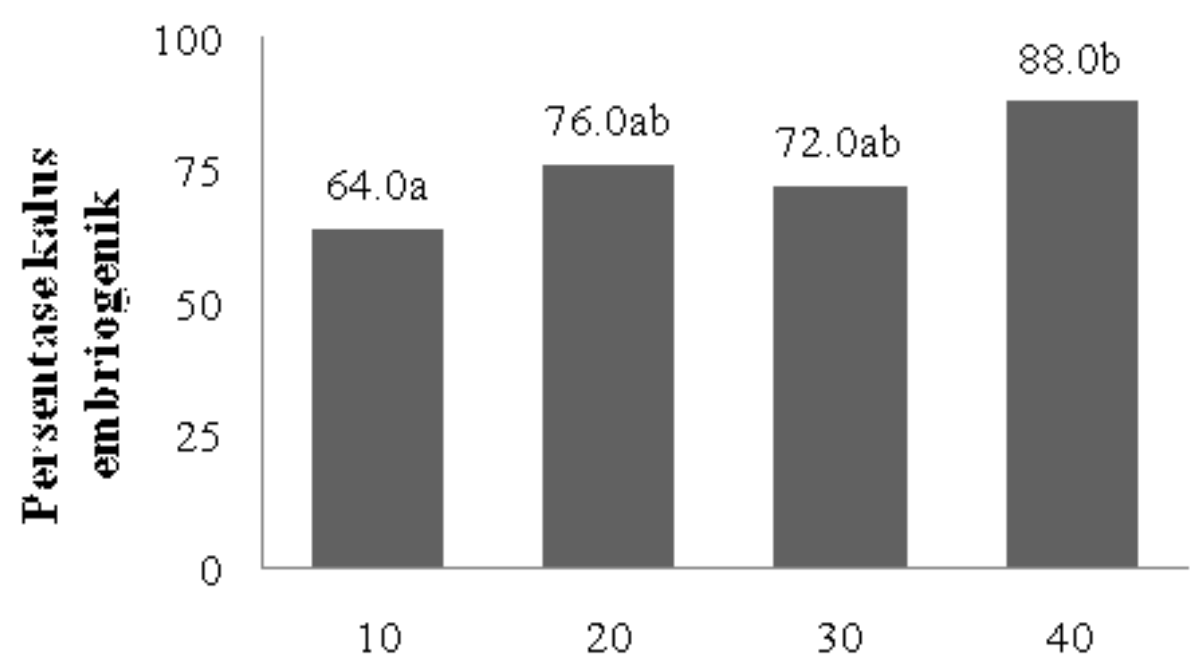

Konsentrasi sularosa g/

Gambar 7. Persentase kalus embriogenik per eksplan pada berbagai macam konsentrasi sukrosa (10, 20, 30, dan $40 \mathrm{~g} / \mathrm{l}$ ) untuk kultivar Sima. Perlakuan yang diikuti oleh huruf yang sama berarti tidak berbeda nyata pengaruhnya menurut BNT 5\% $(21,41)$

Gula merupakan salah satu komponen organik yang harus diberikan ke dalam media tumbuh disamping sebagai sumber karbon, juga berguna untuk mempertahankan tekanan osmotik media. Oleh karena itu, penambahan sukrosa yang relatif tinggi dalam media kultur untuk tanaman tertentu justru akan menghambat pertumbuhan sel-sel somatik. Hal ini akibat tekanan osmotik yang terlalu tinggi, sehingga lebih lanjut dapat mengakibatkan kematian sel-sel akibat terjadinya lisis atau pecahnya dinding sel (Gandawijaya, 1998).

\section{KESIMPULAN}

Dari hasil penelitian dan pengamatan yang telah dilakukan, maka dapat disimpulkan sebagai berikut :
1. Pada kultivar Jerapah, konsentrasi sukrosa berpengaruh terhadap rata-rata jumlah embrio somatik per eksplan dan persentase kalus embriogenik. Konsentrasi sukrosa dalam media yang baik dalam menghasilkan rata-rata embrio somatik per eksplan adalah 20 g/l. konsentrasi sukrosa dalam media yang optimum dalam menghasilkan pesentase kalus embriogenik adalah 10 dan $20 \mathrm{~g} / 1$.

2. Pada kultivar Sima, konsentrasi sukrosa dalam media yang baik dalam menghasilkan rata-rata embrio somatik per eksplan adalah $30 \mathrm{~g} / 1$. konsentrasi sukrosa dalam media yang optimum dalam menghasilkan persentase kalus embriogenik adalah $40 \mathrm{~g} / \mathrm{l}$. 


\section{DAFTAR PUSTAKA}

Eapen, S. dan L. George. 1993. Somatic Embryogenesis in Peanut : Influence of Growth Regulators and Sugars, Plant Cell Tissue and Organ Culture 35 : 151156.

Edy, A., H. Mat Akin, dan H, Pujisiswanto. 2008. Induksi Embrio Somatik dan Akilimatisasi, Evaluasi Produksi dan Genetik (Tanaman Hasil Regenerasi Padda Beberapa Varietas Kacang Tanah. http://digilib.unila.ac.id/go.php?i d=laptunilapp-gdl-res-2008akariedysp 1165.

Finner, J. J., T.S. Cheng, and D.P.S. Verma. 1996. Soybean Transformation : Technologies and Progress. In Verma, D.P.S. and R.C. Shomaker (Eds). Soybean : Genetics moleculer Biology, and Biotechnology, Biotechnologz in Agriculture No. 14. CAB international.

Gandawijaya, D. 1998. Pengaruh sukrosa dan glutamine pada kultur anter solanum khasianum Clarke. J. Ilmiah Biologi 4: 98-102.

George, E.F. and P.D. Sherrington. 1984. Plant Propagation by Tissue Culture. Exegetics Ltd. England. $709 \mathrm{p}$.

Gunawan, L. W. 1988. Teknik Kultur Jaringan Tumbuhan. Institut Pertanian Bogor. Bogor.
Hendaryono, D.P.S. dan A. Wijayani. 2002. Teknik Kultur Jaringan. Karnisius. Yogyakarta.

Heriyanto dan H. Subagio. 1998. Prospek Usaha Tani Kacang Tanah di Indonesia. Dalam A. Harsono, $N$ Nugrahaeni, A. Taufiq, dan A. Winarto (Eds.). Teknologi untuk Peningkatan Produksi dan Nilai Tambah Kacang Tanah. Edisi Khusus Balitkabi. Malang. 12:113.

Livingstone, D.M., and R.G. Birch. 1996. Efficient transformation and regeneration of diverse cultivars of peanut (Arachis hypogaea) by particle bombardment into embryogenic callus produced from mature seeds. Departement of botany, The University of Queensland, Brisbane, Australia. $14 \mathrm{p}$.

Srilestari, R. 2005. Induksi embrio somatik kacang tanah pada berbagai macam vitamin dan sukrosa. Jurnal Ilmu Pertanian Indonesia. Vol 10 (1) : 1-6.

Sulichantini, E. 1998. Induksi embrio somatik dari eksplan poros embrio dan leaflet beberapa kultivar kacang tanah di Indonesia. Tesis S-2. Institut Pertanian Bogor. Bogor. 85 hal.

Yusnita. 2003. Kultur Jaringan "Cara Memperbanyak Tanaman Secara Efisien”. PT Agro Media Pustaka. Boggor. 105 hlm. 
Zuyasna, H. Aswidinoor dan Sudarsono.

2005. Studi genetik daya regenerasi embrio somatik dari eksplan daun embrio kacang tanah (Arachis hypogaea L.). J. Agrista, IX (1) : 105-117.

* Dosen Program Studi Agribisnis, FST UIN Syarif Hidayatullah Jakarta (Email: titikinayah08@gmail.com) 